\title{
FEEDING IN NUDIBRANCH LARVAE
}

\author{
By T. E. ThOMPSON \\ Marine Biological Station, Port Erin, Isle of Man
}

(Text-figs. $\mathrm{I}-7$ )

No account exists of the mechanism of food collection of nudibranch larvae, and, in fact, it has been considered unlikely that feeding does take place in these forms. Thorson (1946, p. 275) states 'Nudibranch larvae will normally take no-or only little-food from the plankton'.

Observations by the present author on larvae of the dorid nudibranch Adalaria proxima (Alder \& Hancock) showed clearly that, although further development with metamorphosis will occur in this species regardless of whether food is provided for the larvae, a feeding mechanism is present and functions throughout pelagic life (Thompson, 1958). Moreover, sections through the larval digestive gland revealed the presence of food vacuoles, proving the ability to assimilate planktonic micro-organisms. These observations provided a stimulus to further work in order to ascertain whether the feeding mechanism described for Adalaria was present in other nudibranchs which possess a free-swimming larval phase.

Accounts of the anatomy of nudibranch veligers are few. Pelseneer (I9II) figured many species, but made little attempt to ascribe functions to the various organs. Rasmussen (1944, I95I) gives more detailed figures of the larvae of a few nudibranchs, but again goes into little functional detail, and fails to orientate the veliger correctly (he repeatedly states that it is the right midgut diverticulum which is the larger whereas his figures leave no doubt that this is incorrect).

\section{MATERIAL AǸD METHODS}

Vestergaard \& Thorson (1938) and Thorson (1946) divide nudibranch larvae into three types, according to the shape of the larval shell. In the present investigation, only species whose larvae belong to Thorson's shell-types B and $\mathrm{C}$ have been treated. There can be little doubt that the type A does not constitute a natural division, but represents a type B shell at an early stage of development (own unpublished observations on Tritonia hombergii Cuvier). The differences in structure between larvae of shell-types B and C, however, are far more striking and significant. Fig. I shows these two nudibranch larval shell types. The type C shell is confined to the families Dendronotidae, Eubranchidae, Tergipedidae and Fionidae; six families, Calmidae, Proctonotidae, Arminidae, Scyllaeidae, Hancockiidae and Lomanotidae have yet to 
be investigated; members of all the other British families which have been studied (see below, and Thorson, I946, p. 269) possess larval shells of type B. (For the reason stated above, the family Tritoniidae is here considered to consist of forms with shells of type B.) In only one instance does it appear that a family contains species with both type B and type $\mathrm{C}$ shells: Coryphella rufibranchialis is said by Thorson (I946) to have a larval shell of type C, whereas $C$. lineata (see below) has a shell of type B. It seems probable that subsequent work will show one or the other of these observations to be incorrect.
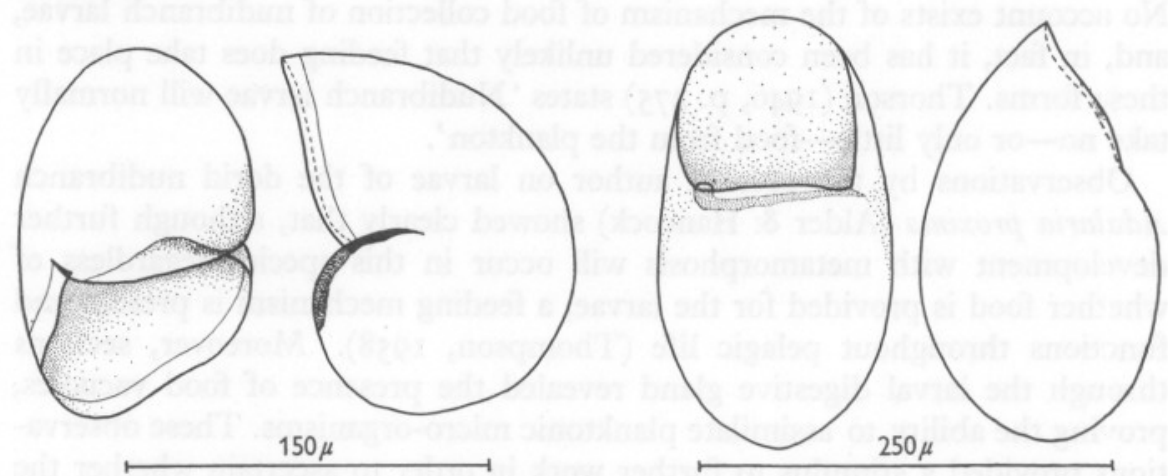

Fig. I. Nudibranch larval shells of Thorson's types B and C: left, postero-ventral and lateral views of forunna tomentosa (type B); right, ventral and lateral views of the larval shell of Trinchesia aurantia (type C).

As a representative of the nudibranch larvae with shells of type B, Archidoris pseudoargus (Rapp) (Glossodorididae) has been investigated in detail, while less detailed observations were made on the following: Forunna tomentosa (Cuvier) (Glossodorididae), Onchidoris fusca (Müller) (Limaciidae), O. muricata (Müller) (Limaciidae), Polycera quadrilineata (Müller) (Limaciidae), Goniodoris nodosa (Montagu) (Limaciidae), Acanthodoris pilosa (Müller) (Limaciidae), Hero formosa (Loven) (Heröidae), Doto coronata (Gmelin) (Dotöidae), Facelina auriculata (Müller) (Facelinidae), Coryphella lineata (Lovén) (Coryphellidae), Limapontia depressa Alder \& Hancock (Limapontiidae), Alderia modesta (Lovén) (Stiligeridae).

As representatives of the shell-type C, observations were made on larvae of Trinchesia aurantia (Alder \& Hancock) (Tergipedidae) and Eubranchus exiguus (Alder \& Hancock) (Eubranchidae).

The nomenclature and classification employed are those advocated by Winckworth (1932, 1951).

All larvae were obtained from egg masses laid and reared in the laboratory. Feeding currents were observed in suspensions of fine carmine particles or of the diatom Phaeodactylum tricornutum Bohlin (from a culture kindly provided by Dr J. M. Kain). Larvae were fixed in hot Perényi's fluid, cleared with 
amyl acetate (Barron, I934) and sectioned at 5-10 $\mu$. Stains employed included Mayer's haemalum, Heidenhain's iron haematoxylin and, as counterstains, eosin and alcian blue $8 \mathrm{GS}$ (Steedman, 1950).

\section{THE LARVA OF ARCHIDORIS PSEUDOARGUS}

The figures display most of the results of this investigation. Figs. 2 and 3 show the extended veliger larvae of the species, Fig. 4 the cephalopedal ciliary apparatus and Figs. 5 and 6 the alimentary canal. Only those features which are not immediately apparent from these figures will be described.
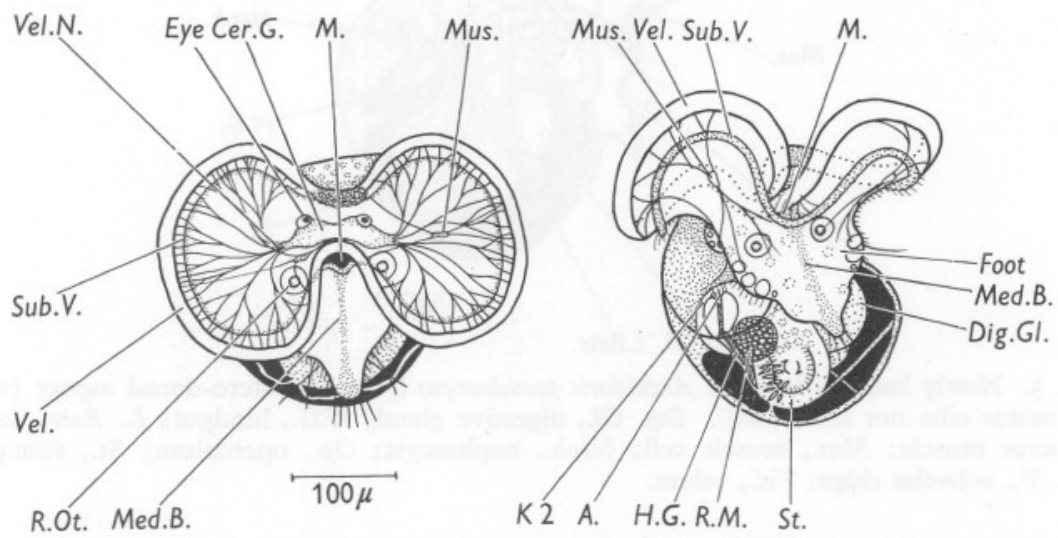

Fig. 2. Eyed larva of Archidoris pseudoargus, 3 days after hatching: left, viewed from the anterior; right, right latero-ventral aspect (velar locomotor cilia not illustrated). $A$., anus; Cer. G., cerebral ganglion; Dig. Gl., digestive gland; H.G., hindgut; K2, larval kidney; M., mouth; Med. B., median pedal band of strong cilia producing the main rejection current; Mus., muscle cell; R.M., right midgut diverticulum; R.Ot., right otocyst; St., stomach; Sub.V., subvelar ridge or subvelum; Vel., velum; Vel.N., nerve fibres from the cerebral ganglia to the velar cells.

The cephalopedal ciliary apparatus (Fig. 4)

The long velar cilia serve a dual purpose in both imparting a forward motion to the larva and bringing a constantly renewed supply of sea water within the influence of the feeding apparatus. Particles brought within the influence of the cilia arranged along the subvelar ridges (Figs. 2-4, Sub.V.) are rapidly conducted towards the mouth. The borders of the mouth (Figs. 2, 4, M.) are strongly ciliated and particles of sufficiently small size (less than $c a$. $15 \mu$ in diameter) are impelled into the foregut.

The long velar cilia can be stopped and started, being under the control of the nervous system (Carter, I926). All the other cilia of the larval body beat continuously, and a feeble feeding current is manifest even when the larva sinks passively with the velum inactive. 
The external surface of the foot is ciliated, these cilia being particularly strongly developed along a narrow zone leading from the ventral border of the mouth to the papillate tip of the foot (Figs. 2, 4, Med.B.). This narrow band forms the main rejection current; particles which are too large to enter the mouth appear to be tipped over its ventral border and are then removed rapidly by this strong stream.

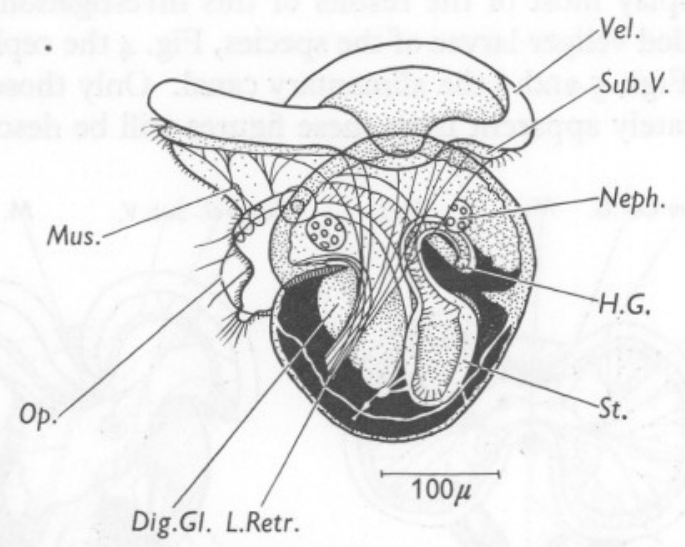

Fig. 3. Newly hatched larva of Archidoris pseudoargus from left latero-dorsal aspect (velar locomotor cilia not illustrated). Dig. Gl., digestive gland; H.G., hindgut; L. Retr., larval retractor muscle; Mus., muscle cell; Neph., nephrocyst; Op., operculum; St., stomach; Sub. V., subvelar ridge; Vel., velum.

\section{The foregut (Fig. 5, F.G.)}

The foregut is strongly ciliated internally, these cilia creating a current which conveys particles from the mouth into the stomach.

\section{The stomach and its diverticula (Fig. 5)}

The stomach is internally ciliated throughout. Short, fast-beating cilia are arranged on a raised band (Figs. 5, 6, Cil.B.) which causes a rapid rotation of particles in the lumen. The direction of rotation was the same in all the individuals observed. Ventrally, close to the openings of the foregut and the midgut diverticula into the stomach (Fig. 6A, F.G.op., R.M.op., Dig.Gl.op.), the cilia are longer and more slow moving. They induce an apparently aimless particle agitation, which may on occasion be seen to become more coordinated and take the form of a rotatory movement in the ventral stomach. A small zone of hyaline, rod-like bodies is present in the ventral stomach wall on the right side (Fig. 6B, Hy.Rods).

The midgut diverticula are a pair, lying symmetrically against the anterolateral walls of the stomach. Both possess lumina; this is more marked in the case of the left diverticulum which is by far the larger. The right diverticulum (Fig. 2, R.M.) consists of a few large yolk-laden cells at hatching; these cells 
decrease in size during later larval life as, presumably, the yolk is utilized. This right diverticulum, as far as could be ascertained, plays no part in digestion.

The left midgut diverticulum or digestive gland (Figs. 2, 3 and 5, Dig.Gl.) is pale green-brown in life, and has a wall of single-cell thickness. It has a crescentic shape, following the line of the whorl of the shell. The cells composing its wall are ciliated and are of two kinds; the majority are cubical digestive cells but there are a few larger cells (mainly lying close to the opening of the organ into the stomach) which have yolk-laden cytoplasm. The nuclei are peripherally placed within all the cells of the digestive gland. Sections through larvae which have been allowed access to Phaeodactylum show large numbers of ingested diatoms enclosed in cytoplasmic food vacuoles

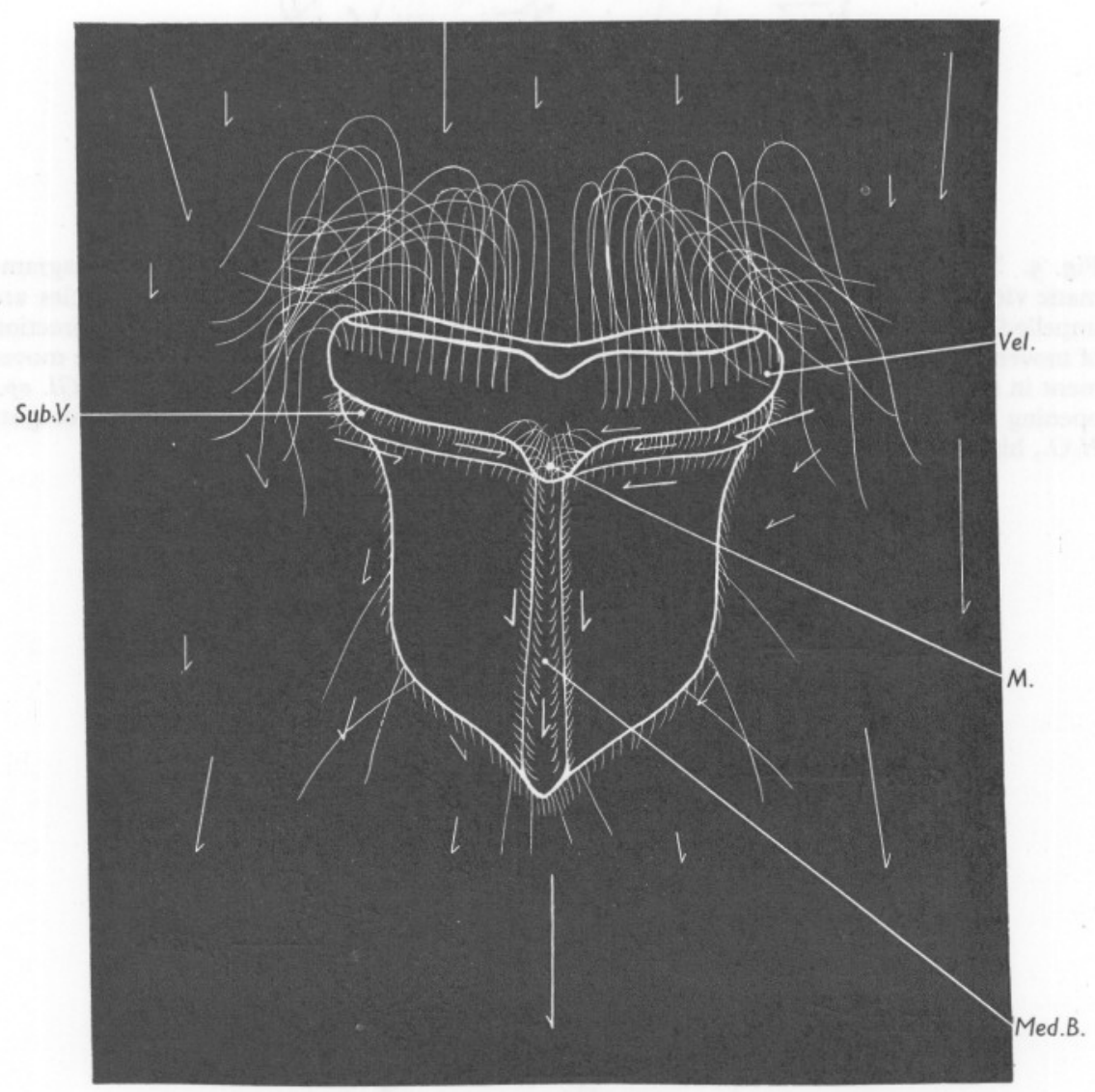

Fig. 4. Cephalopedal ciliary apparatus of larval Archidoris pseudoargus: semi-diagrammatic view from ventral aspect. The arrows indicate the direction in which particles are impelled. M., mouth; Med. B., median pedal band; Sub. V., subvelar ridge; Vel., velum. 


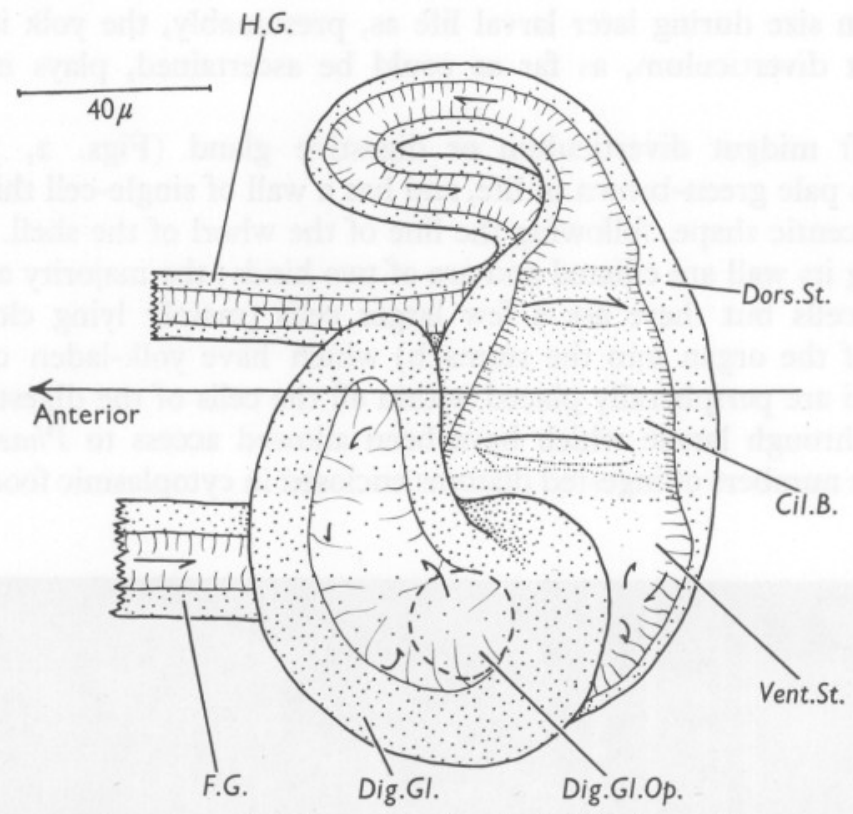

Fig. 5. The stomach and associated organs in larval Archidoris pseudoargus: semi-diagrammatic view from left lateral aspect. The arrows indicate the direction in which particles are impelled. In the region of the raised band of stomach cilia, the solid arrows show the direction of movement of particles in the higher focal levels whereas the dotted arrows show the movement in the lower levels. Cil. B., raised band of cilia; Dig. Gl., digestive gland; Dig. Gl. op., opening of digestive gland into stomach; Dors. St., dorsal region of stomach; F.G., foregut; H.G., hindgut; Vent. St., ventral region of stomach.

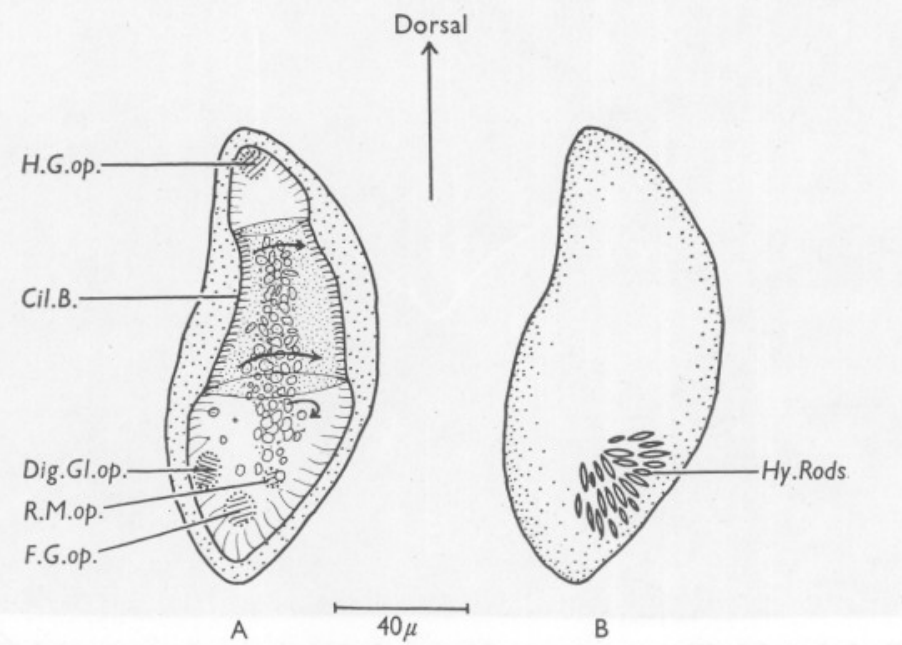

Fig. 6. The stomach in larval Archidoris pseudoargus: semi-diagrammatic view from the posterior aspect. A, in optical section; B, surface view only. Cil.B., raised band of cilia; Dig. Gl.op., opening of digestive gland into stomach; F.G.op., opening of foregut into stomach; H.G. op., opening of hindgut into stomach; Hy. Rods, zone of hyaline rod-like bodies; R.M. $o p$. opening of right midgut diverticulum into stomach. 
in the digestive cells. The food vacuoles are nearly always situated close to the nuclei. Particles of carmine powder were not taken up by the digestive gland cells, as far as could be ascertained.

\section{The hindgut (Figs. 2, 5, H.G.).}

This is an internally ciliated tube, leaving the midgut dorsally and passing to the anus, situated in the mantle fold, latero-ventrally on the right side. Metachronal waves passing towards the stomach are always clearly evident. The anal opening is immediately ventral to the opening of the larval kidney (Fig. 2, K2). A pair of colourless vesicles of unknown function lie embedded in the mantle fold close to the anus (Fig. 2, $A$.). The cilia of the mantle fold and a zone of especially strong cilia on the right side of the foot (see Fig. 2) disperse the faeces as they emerge from the anus. The faeces are not cemented together into strings or pellets as they are in post-larval stages.

\section{Course of particles entering the mouth}

Particles on entering the mouth are rapidly transported by the foregut cilia into the stomach. In the stomach the raised ciliary band brings about a rapid rotation, a loose rod of particles soon being formed. The ventral extremity of this rod always is close to the patch of hyaline rod-shaped bodies in the stomach wall (see Fig. 6); it seems likely that this patch is the site of some enzymatic activity. Particles apparently haphazardly leave the rod of food particles and are impelled by the more sluggish cilia of the ventral stomach into the digestive gland. When in the lumen of the digestive gland, a proportion of them are ingested.

Millar (1955), working on larvae of Ostrea edulis, states that 'it is a matter of chance whether material drawn off into the midgut and thence passed to the rectum has been in the stomach for a short or a long time'; although this may be true in the larval oyster, and although no definite proof to the contrary can be provided by the present investigation, the impression was gained that a definite pattern of treatment for each new incoming particle was present, and that no particle of food value was passed directly into the hindgut unless a superabundance of such particles was present.

Passage of particles from the stomach into the digestive gland is brought about by ciliary means; nevertheless, contraction of muscle fibres in the membranes enclosing the visceral organs (Thompson, 1958) can bring about partial contraction of the organs and probably aids this interchange. Millar (1955) described a similar phenomenon in Ostrea.

\section{OTHER SPECIES}

In all the other nudibranch larvae examined, with the partial exceptions of Trinchesia aurantia and Eubranchus exiguus, the feeding mechanism is as described for Archidoris pseudoargus. Minor specific differences occur, such 
as the black pigmented mouth of the larva of Limapontia depressa or the hyaline velar granules of Hero formosa, but the functions of the various organs and even their relative state of development is closely similar in all. Even the direction of rotation of particles within the stomach was in all cases the same as that shown for Archidoris in Fig. 5. (Yonge, 1926, found that the direction of rotation of particles within the stomach of larval Ostrea varied from one individual to another.)

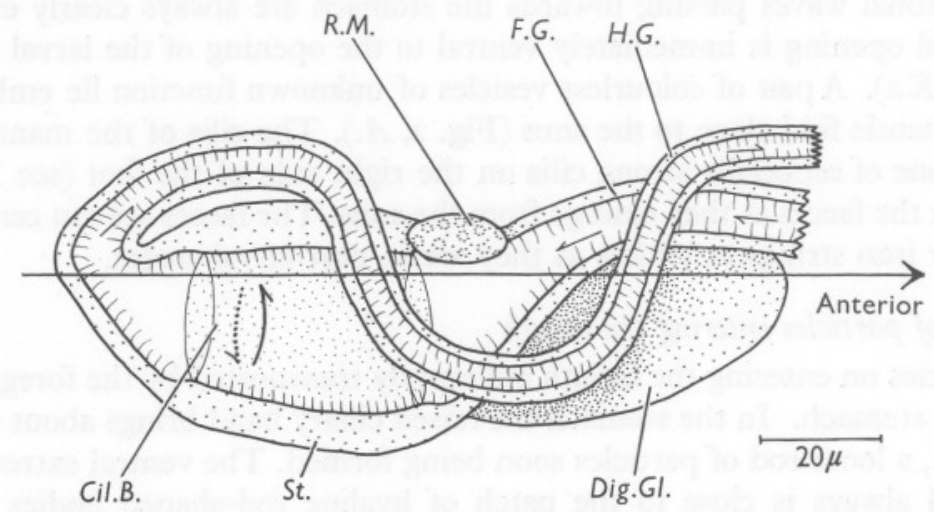

Fig. 7. The stomach and associated organs in larval Trinchesia aurantia from right lateral aspect. The arrows indicate the direction in which particles are impelled. In the region of the raised band of stomach cilia, the solid arrow shows the direction of movement of particles in the higher focal levels whereas the dotted arrow shows the movement in the lower levels. Cil.B., raised band of cilia; Dig. Gl., digestive gland; F.G., foregut; H.G., hindgut; R.M., right midgut diverticulum; St., stomach.

The larval feeding mechanism of Trinchesia aurantia and Eubranchus exiguus in functional essentials differs not at all from that found in larvae of shell-type B, but significant differences are manifest in the arrangement of the visceral organs. Fig. 7 shows the larval gut of Trinchesia aurantia; it is obvious that the long axis of the stomach in this species lies along the antero-posterior axis of the larva, while in Archidoris (see Fig. 5) and all the other nudibranchs of shell-type B, it lies at right angles to this. The significance of this is not known; in any event the mechanism of food capture in Trinchesia aurantia and Eubranchus exiguus does not differ from the general pattern, nor could any difference in the treatment of ingested particles be detected. The absence of hyaline rods in the stomach wall of these two species, however, may be of importance.

\section{DISCUSSION}

There can be no doubt that nudibranch larvae feed during planktonic life. That this planktonic period is a short one is highly probable (Thorson, 1946) but to dismiss the group as of no importance in the plankton would be inaccurate. All British nudibranchs (leaving aside the Ascoglossa) have a planktonic 
larval phase and each individual adult produces very large numbers of eggs during the spawning season.

The mechanism of feeding was very similar in all the species investigated, some difference, however, existing between the orientation of the stomach of the larval shell-types B and C of Thorson (1946). Thorson's contention that nudibranch larvae with shells of type $\mathrm{C}$ are more fitted for planktonic life than those of type B finds no support from this investigation: larvae of the two types possess the same organs developed to the same degree.

The mechanism of particle capture in nudibranch larvae is similar in many respects to that described by Yonge (1926) for larvae of Ostrea, except that in nudibranchs the subvelar cilia are placed on a pair of prominent ridges. Movement of particles between the lumina of the visceral organs in larval nudibranchs is accomplished chiefly by ciliary means, assisted probably by the muscular movements which have been observed to occur; in Ostrea larvae, however, Millar (I955) states that particles pass into and out of the midgut diverticula chiefly or solely as the result of muscular action. The absence of the crystalline style and gastric shield and the unimportant role of the right midgut diverticulum are further differences from the larvae of lamellibranchs. It is possible, however, that the numerous hyaline rods in the nudibranch larval stomach wall (Fig. 6B, Hy.Rods), occupying a similar position in all those species in which it is present, serve a function similar to that of the style. The rotation of the particle mass against the site of these hyaline rods suggests strongly this interpretation of their function.

Cellular ingestion of food particles occurs solely in the digestive gland. In nudibranch larvae the right midgut diverticulum plays no part in the digestive process and the foregut and hindgut are concerned simply with the conduction of particles. The contents of the stomach and digestive gland in sections stain lightly with mucus stains and with haematoxylin, suggesting that intracellular digestion, which undoubtedly is the chief method of particle assimilation, may be aided by the production of extra-cellular enzymes. The presence of diffuse organic matter in the lumen of the gut is difficult to interpret otherwise.

The author is indebted to Mr J. S. Colman for helpful criticism and for the provision of laboratory facilities. The work was done while the author was the holder of a Leverhulme Fellowship in the University of Liverpool. The specimens of Limapontia depressa were most kindly brought by Mr A. Hopson from Flatford Mill, and those of Alderia modesta sent by Dr T. Gascoigne from Anglesey.

\section{SUMMARY}

The mechanism of food capture and the movement of food particles within the gut are described from observations on live and sectioned veliger larvae of the glossodorid nudibranch Archidoris pseudoargus. 
Less detailed observations on the larvae of twelve other nudibranch species with shells of Thorson's type B, and of two species with shells of type C, showed similar mechanisms to exist in all.

Ingestion and assimilation of food particles occur solely in the left midgut diverticulum or digestive gland; some indirect evidence of the presence of extra-cellular enzymes is described.

\section{REFERENCES}

BARRon, D. H., I934. Amyl acetate: a useful solvent for embedding masses. Anat. Rec., Vol. 59, pp. I-3.

CARTER, G. S., 1926. On the nervous control of the velar cilia of the nudibranch veliger. Brit. F. exp. Biol., Vol. 4, pp. 1-26.

Millar, R. H., I955. Notes on the mechanism of food movement in the gut of the larval oyster, Ostrea edulis. Quart. F. micr. Sci., Vol. 96, pp. 539-44.

PelseneER, P., Igri. Recherches sur l'embryologie des gastropodes. Mém. Acad. R. Belg. Cl.Sci., Ser. II, 3, livr. 6, pp. I-I67.

RASMUSSEN, E., 1944. Faunistic and biological notes on marine invertebrates I. The eggs and larvae of Brachystomia rissoides (Hanl.), Eulimella nitidissima (Mont.), Retusa truncatula (Brug.) and Embletonia pallida (Alder \& Hancock), (Gastropoda marina). Vidensk. Medd. dansk naturh. Foren. Kbh., Bd. 107, pp. 207-33.

- 195I. Faunistic and biological notes on marine invertebrates. II. The eggs and larvae of some Danish marine gastropods. Vidensk. Medd. dansk naturh. Foren. $K b h$., Bd. I13, pp. 202-49.

Steedman, H. F., I950. Alcian blue 8GS: a new stain for mucin. Quart. F. micr. Sci., Vol. 91, pp. 477-9.

Thompson, T. E., 1958. The natural history, embryology, larval biology and postlarval development of Adalaria proxima (Alder \& Hancock) (Gastropoda Opisthobranchia). Phil. Trans. B, Vol. 242, pp. I-58.

Thorson, G., 1946. Reproduction and larval development of Danish marine bottom invertebrates, with special reference to the planktonic larvae in the Sound (Øresund). Medd. Komm. Havundersøg, Kbh., Ser. Plankt, Bd. 4, No. I, 523 pp.

VestergaARD, K. \& Thorson, G., 1938. Über den laich und die larven von Duvaucelia plebeja, Polycera quadrilineata, Eubranchus pallidus and Limapontia capitata (Gastropoda, Opisthobranchiata). Zool. Anz., Bd. I24, pp. I29-38.

WINCKWORTH, R., I932. The British marine Mollusca. f. Conchol., Vol. I9, pp. 2 I I-52.

_ I95I. A list of the marine Mollusca of the British Isles: additions and corrections. f. Conchol., Vol. 23, pp. 13I-4.

YoNGE, C. M., 1926. Structure and physiology of the organs of feeding and digestion in Ostrea edulis. F. mar. biol. Ass. U.K., Vol. I4, pp. 295-386. 